\title{
Developing a web-based application for school councelling and guidance during COVID-19 Pandemic
}

\author{
Lulud Oktaviani $\mathrm{i}^{\mathrm{a}, 1, *}$, Yusra Fernando $^{\mathrm{b}, 2}$, Randi Romadhoni $\mathrm{i}^{\mathrm{b}, 3}$, Nia Noviana $^{\mathrm{a}, 4}$ \\ ${ }^{a}$ Faculty of Arts and Education, Universitas Teknokrat Indonesia, JI. ZA Pagar Alam 9-11 Kedaton, Bandarlampung, Lampung 35132, Indonesia \\ ${ }^{b}$ Faculty of Engineering and Computer Science, Universitas Teknokrat Indonesia, JI. ZA Pagar Alam 9-11 Kedaton, Bandarlampung, Lampung 35132, \\ Indonesia \\ 1/ulud_oktaviani@teknokrat.ac.id*,2yusra.fernando@teknokrat.ac.id, ${ }^{3}$ randy.madhoni@gmail.com, ${ }^{4}$ novianania599@gmail.com \\ * Corresponding author
}

\section{ARTICLE INFO}

\section{Article history}

Received: 2021-08-03

Revised: 2021-08-31

Accepted: 2021-09-23

Published: 2021-09-23

\section{Keywords}

Covid-19

Counseling and Guidance

Web-based Application

Psychology Education

\section{ABSTRACT}

Covid-19 pandemic that hit Indonesia since 2020 has made changes in the educational aspect where teachers must be able to adapt to the use of technology and minimize physical interaction. As a result, this also affects students' well-being where some new things emerged such as learning process that was initially conducted face-to-face, currently shifted into distance learning. Subsequently, students need more psychological guidance from the school especially if the counselling and guidance can be accessed online to maintain students' conditions and the quality of the learning itself. Therefore, this service team aims to improve the counseling guidance system of SMK Amal Bakti Jati Mulyo of South Lampung during COVID-19 pandemic by developing a website-based counseling application. The methods used in this activity were lecture and questionnaires, where lecture is for application socialization and questionnaires were to see the participants' attitude regarding to the use of the website-based counselling and guidance application. This service has contributed that by developing this application system, students could do psychological consultation during covid-19 pandemic safety without having physical interaction.

\begin{abstract}
Mengembangkan aplikasi Bimbingan dan Konseling Sekolah Berbasis Web selama Pandemi COVID19. Pandemi Covid-19 yang melanda Indonesia sejak tahun 2020 membuat perubahan dalam aspek pendidikan dimana pengajar harus dapat beradaptasi dengan penggunaan teknologi dan meminimalisasi pertemuan. Hal ini berdampak pada psikologi siswa dimana beberapa hal baru seperti proses belajar yang awalnya tatap muka menjadi jarak jauh sehingga siswa lebih membutuhkan bimbingan psikologi dari pihak sekolah utamanya yang dapat diakses secara jarak jauh untuk mempertahankan kondisi siswa dan kualitas belajar itu sendiri. Oleh karena itu, tim pengabdian ini bertujuan untuk meningkatkan system bimbingan konseling SMK Amal Bakti Jati Mulyo Lampung Selatan di masa pandemi covid-19 dengan mengenmbangkan aplikasi bimbingan konseling jarak jauh berbasis website. Metode pelaksanaan kegiatan ini adalah ceramah dan angket, dimana ceramah untuk sosialisasi aplikasi dan angket untuk mengukur sikap peserta pengabdian dalam penggunaan aplikasi bimbingan konseling jarak jauh bernasis website. Hasil pengabdian dari pengembangan system aplikasi ini, siswa dapat melakukan konsultasi psikologi selama pandemi covid-19 dengan aman tanpa melakukan pertemuan atau kontak fisik.
\end{abstract}

Copyright (C) 2021, Oktaviani et al This is an open access article under the CC-BY-SA license

\section{Check for updates}

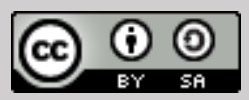

How to cite: Oktaviani, L., Yusra, F., Romadhoni, R., \& Noviana, N. (2021). Developing a web-based application for school councelling and guidance during COVID-19 Pandemic. Journal of Community Service and Empowerment, 2(3), 110-117. doi: https://doi.org/10.22219/ jcse.v2i3.17630

\section{INTRODUCTION}

Covid-19 pandemic that spreads around the world since 2020 has caused changing in many aspects of human life, one of them is education aspect. Based on the Decree of Ministry of Education number 4 of 2020 about how to conduct teaching and learning activities and number 15 of 2020 about learning from during covid-19 pandemic, teachers have 
use technology to hold online learning as the instruction of The Ministry of Education. Despite of the difference abilities and facilities among the school in Indonesia (Riskiono et al, 2021), teachers have to adapt and becomes a part of digital native. Moreover, technology used can attract students' attention and motivation (Oktaviani and Desiarti, 2017), stimulate students' autonomous learning because it can access anytime and anywhere even without the teachers' presence (Aminatun and Oktaviani, 2019), and boost students' mastery of material (Simamora and Oktaviani, 2020). Furthermore, the technology usage in teaching and learning activity can also give benefits for teachers and show their professionalism (Oktaviani et al, 2020).

However, the sudden change of teaching and learning activity causes some problems like less competence of technology usage, limited access of internet, and even psychological problem to the students (Aji, 2020). According to Yazid and Neviyarni (2021), online learning can cause psychological problems, such as decreased immunity and high anxiety. The team also did a preliminary study questionnaire to SMA Amal Bakti Students as follows:

Table 1. Preliminary study toward online learning

\begin{tabular}{|c|c|c|c|}
\hline No. & Statements & Yes (\%) & No (\%) \\
\hline 1 & Covid-19 Pandemic affects the quality of learning. & 83 & 17 \\
\hline 2 & Covid-19 Pandemic has changed my style of learning. & 95 & 5 \\
\hline 3 & $\begin{array}{l}\text { Covid-19 Pandemic limits my interaction and communication with my teachers and } \\
\text { friends. }\end{array}$ & 98 & 2 \\
\hline 4 & $\begin{array}{l}\text { Covid-19 Pandemic make me easier to follow teachers' explanation by using } \\
\text { technology. }\end{array}$ & 54 & 46 \\
\hline 5 & During online learning, I feel anxious. & 68 & 32 \\
\hline 6 & During online learning, I feel excited. & 36 & 64 \\
\hline 7 & During online learning, I feel tired easily. & 74 & 26 \\
\hline 8 & During online learning, I feel happy. & 42 & 58 \\
\hline
\end{tabular}

From Table 1 above, it can be seen that online learning during covid-19 pandemic does affect students' way of learning and $95 \%$ respondents said it limits the interaction between teacher and students. By looking at the result, almost more than 50\% students revealed that covid-19 pandemic has led them to feel anxious, not excited, tired and unhappy. Thus, the schools have to give more attention to the students in order to maintain the quality of teaching and learning and monitor psychology of the students.

Based on the condition above, this community service team tries to solve the problems by developing a web-based application to enhance the counselling and guidance system of SMK Amal Bakti Jati Mulyo, South Lampung. This concern does support in achieving one of Sustainable Development Goals (SDGs), it is to ensure healthy lives and support wellbeing for all at all ages. Particularly this service focuses on high school students who are susceptible in their psychological well-being.

\section{METHOD}

\section{Implementation}

This program used lecture and questionnaires method. Lecture was used to socialize the web-based application of counselling and guidance. It is in line with Rikawati and Sitinjak (2020) that stated lecture is a method to deliver the material which may involve question and answer and discussion session. Besides, this team also used questionnaires to see the respondents' attitude toward the counselling and guidance system used web-based application. Likert Scale was used because according to Kriksciuniene et al (2019), it is used when the data about the agreement of a group statements/questions is collected and to measure the attitude of the respondents. There were four scales in this questionnaire which shown in the Table 2.

Table 2. Likert Scales

\begin{tabular}{cc}
\hline Scales & Attitudes \\
\hline 1 & Strongly Disagree \\
2 & Disagree \\
3 & Agree \\
4 & Strongly Agree \\
\hline
\end{tabular}

Four scales were used to reduce the ambiguity and minimize the less variation of the result. As Widhiarso (2020) said that respondents tend to choose middle option or neutral provided and can caused bias questionnaires result. Thus, the team decided to used four scales only. 


\section{Participants}

This service program was held at SMK Amal Bakti Jatimulyo which is located in JL. Panembahan Senopati, Jatimulyo, Jati Agung, Margo Lestari, South Lampung, Lampung (Figure 1). This school was chosen because this was a program called Pengabdian Sekolah Binaan initiated by Universitas Teknokrat Indonesia (UTI). There are five majors in this vocational school, they are Network Computer Engineering, Computer Engineering, Online Business, Accounting, and Office. Participations of this program was Gugus Tugas Penegak Disiplin (GTPD) which has responsible to monitor students' problems. The location of UTI and the school is 9,7 km and 21 minutes by car.
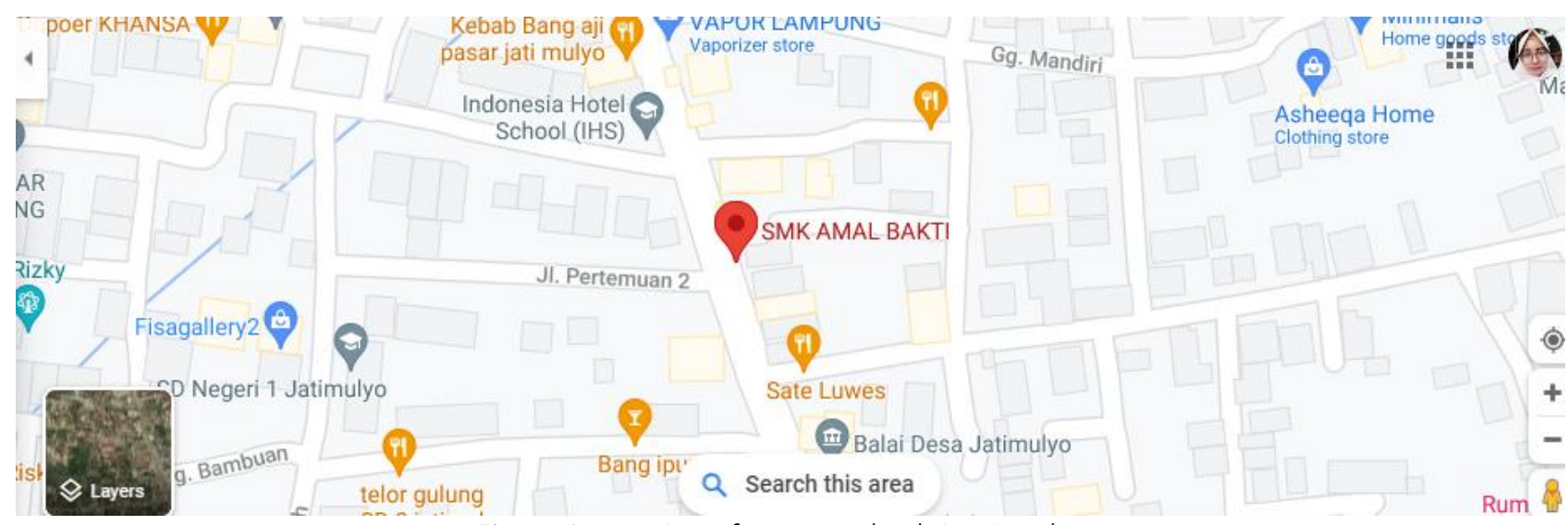

Figure 1. Location of SMK Amal Bakti Jati Mulyo

\section{Procedure}

The procedure has been done by the following activities (Figure 2).
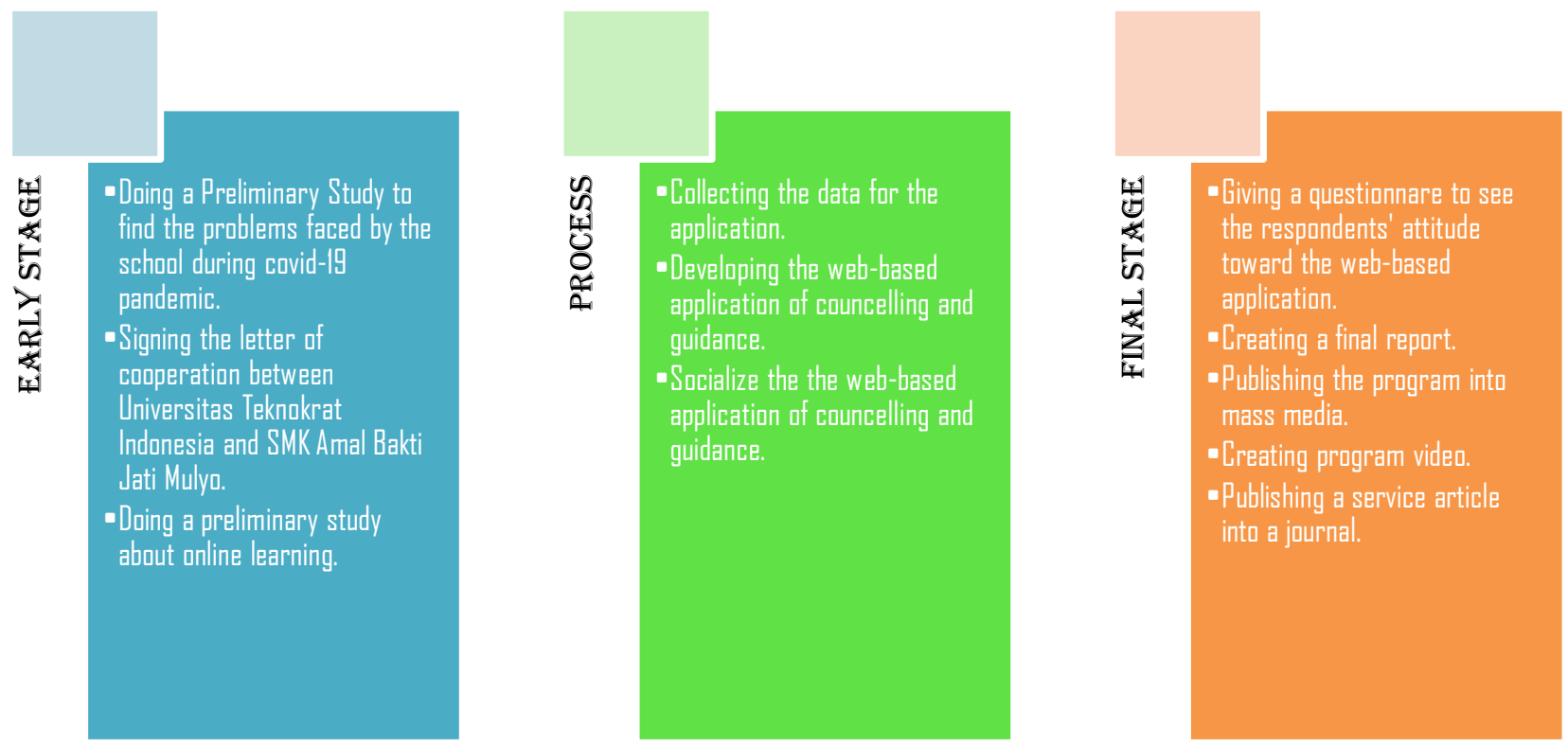

Figure 2. Stages of the service program

\section{RESULTS AND DISCUSSION}

The lecture activity was done to Gugus Tugas Penegak Disiplin (GTPD) of SMK Amal Bakti Jati Mulyo of South Lampung because the school still implemented learning from home and the amount of people in a meeting is limited. There were nineteen students of GTPD and one counselling and guidance teacher. It can be seen in the Figure 3.

For this socialization, the GTPD and the teacher were guided about how to register, use, add and remove the problems, give solutions, and monitor the students' problem by using a web-based application of counseling and guidance. The Figure 4 shows the screen capture of the web-based application of counselling and guidance. 


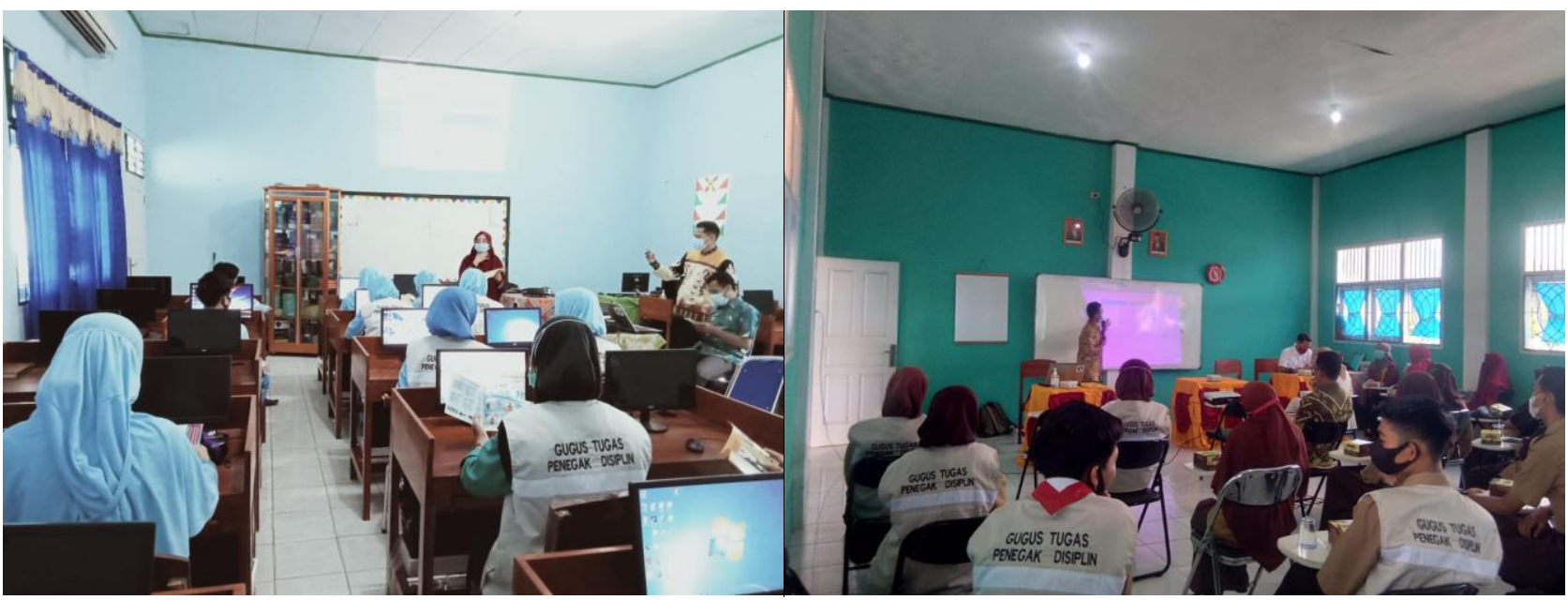

Figure 3. Socialization of web-based application of counselling and guidance

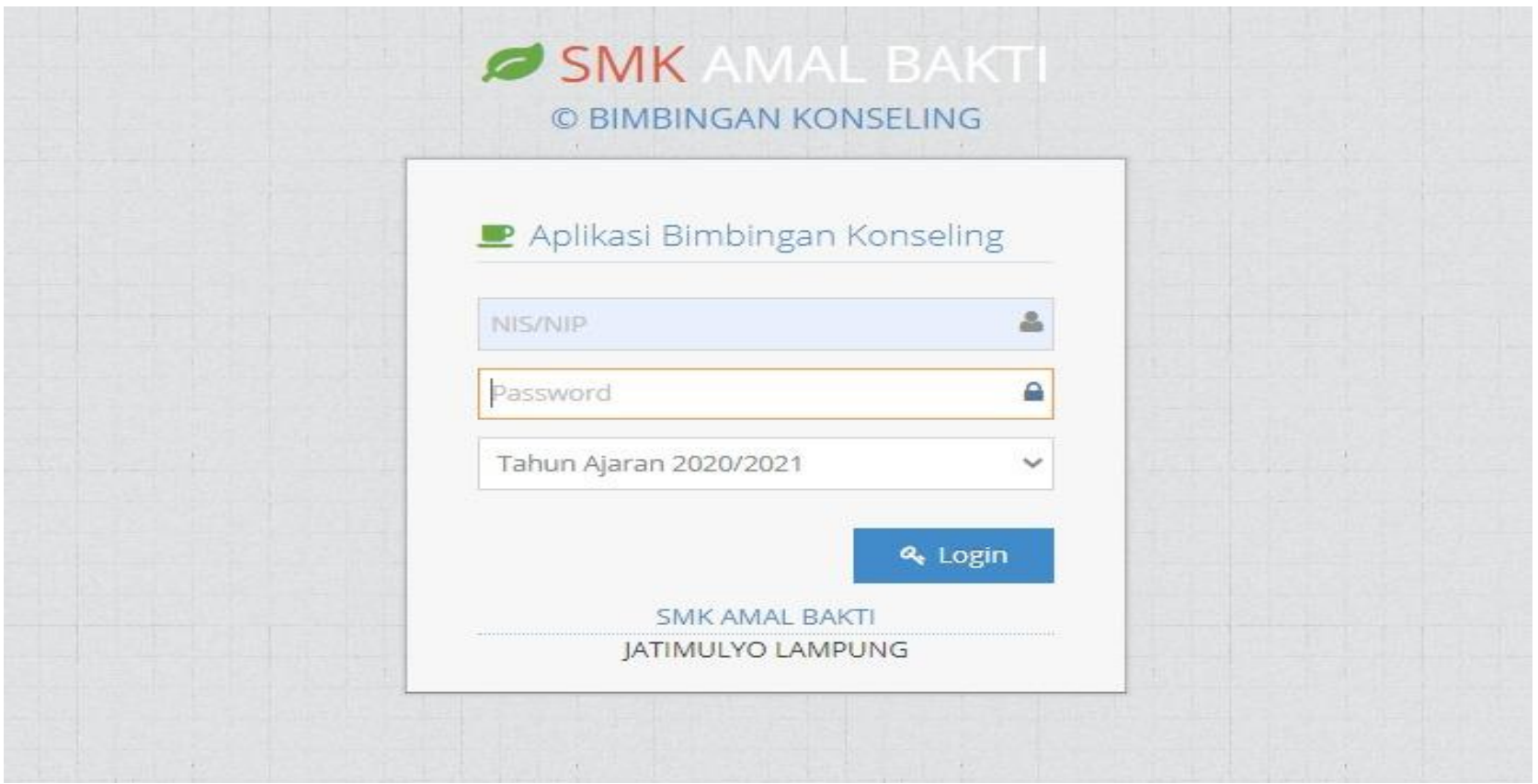

Figure 4. The home page of web-based application of counselling and guidance

The students need to insert their students' number, password they have created, and academic year if they are going to login to the web-based application of counselling and guidance. The academic year here to indicate or group their consultation activities (Figure 5).

凡 Home , Dashboard

Dashboard » Halaman Utama

$\checkmark$ Selamat Datang di Sistem BK SMK Amal Bakt

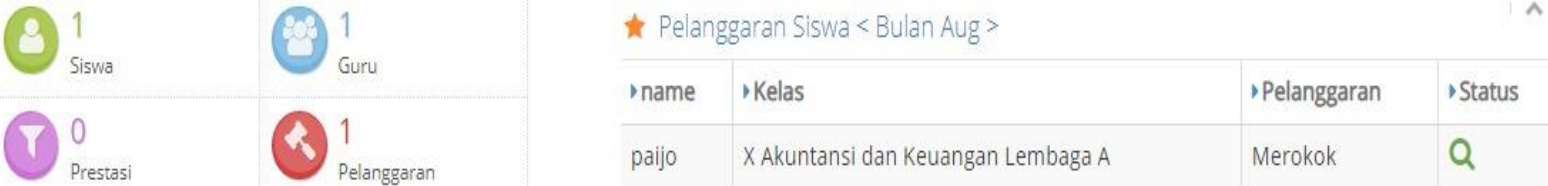

Figure 5. Main page of web-based application of counselling and guidance 
After the students succesfully login into the application, they go directly to the main page where they can see the interaction process, input a new consultation, monitor their activities like a reward and punishment during their study at SMK Amal Bakti Jati Mulyom South Lampung.

\section{Tambah Data Berhasil}

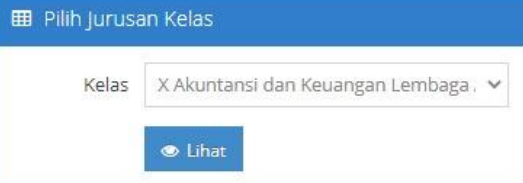

\begin{tabular}{l} 
E Keterangan Tabel \\
SWB $\rightarrow$ Sholat Wajib Berjamaah \\
KBA $\rightarrow$ Kebiasaan Membaca Al-Quran \\
SS $\rightarrow$ Sholat Sunnah \\
KRJ $\rightarrow$ Kerajinan \\
KDS $\rightarrow$ Kedisiplinan \\
KRP $\rightarrow$ Kerapihan \\
\hline
\end{tabular}

\begin{tabular}{|c|c|c|c|c|c|c|c|c|c|c|c|}
\hline a) Cetak & & & & & & & & Q & 约 & 气 & $\theta$ \\
\hline \multicolumn{12}{|c|}{ Results for "X Akuntansi dan Keuangan Lembaga A" } \\
\hline \multicolumn{12}{|c|}{ Display $10 \sim$ records } \\
\hline No $=$ & Nama Siswa & 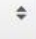 & SWB & KBA & SS & KRJ & KDS & KRP & \multicolumn{3}{|c|}{ Status } \\
\hline 1 & paijo & & 4 & 4 & 5 & 4 & 3 & 4 & \multicolumn{3}{|c|}{$\theta$} \\
\hline \multicolumn{8}{|c|}{ Showing 1 to 1 of 1 entries } & Previous & \multicolumn{3}{|c|}{ Next } \\
\hline
\end{tabular}

Figure 6. The data of counselling

The aim of this web-based application is to create a means of communication during covid-19 pandemic, so there is slightly difference of the appearance if it is accessed by the students and GTPD or a counselling guidance. Figure 7 shows an appearance if it is accessed by GTPD or a counselling teacher.

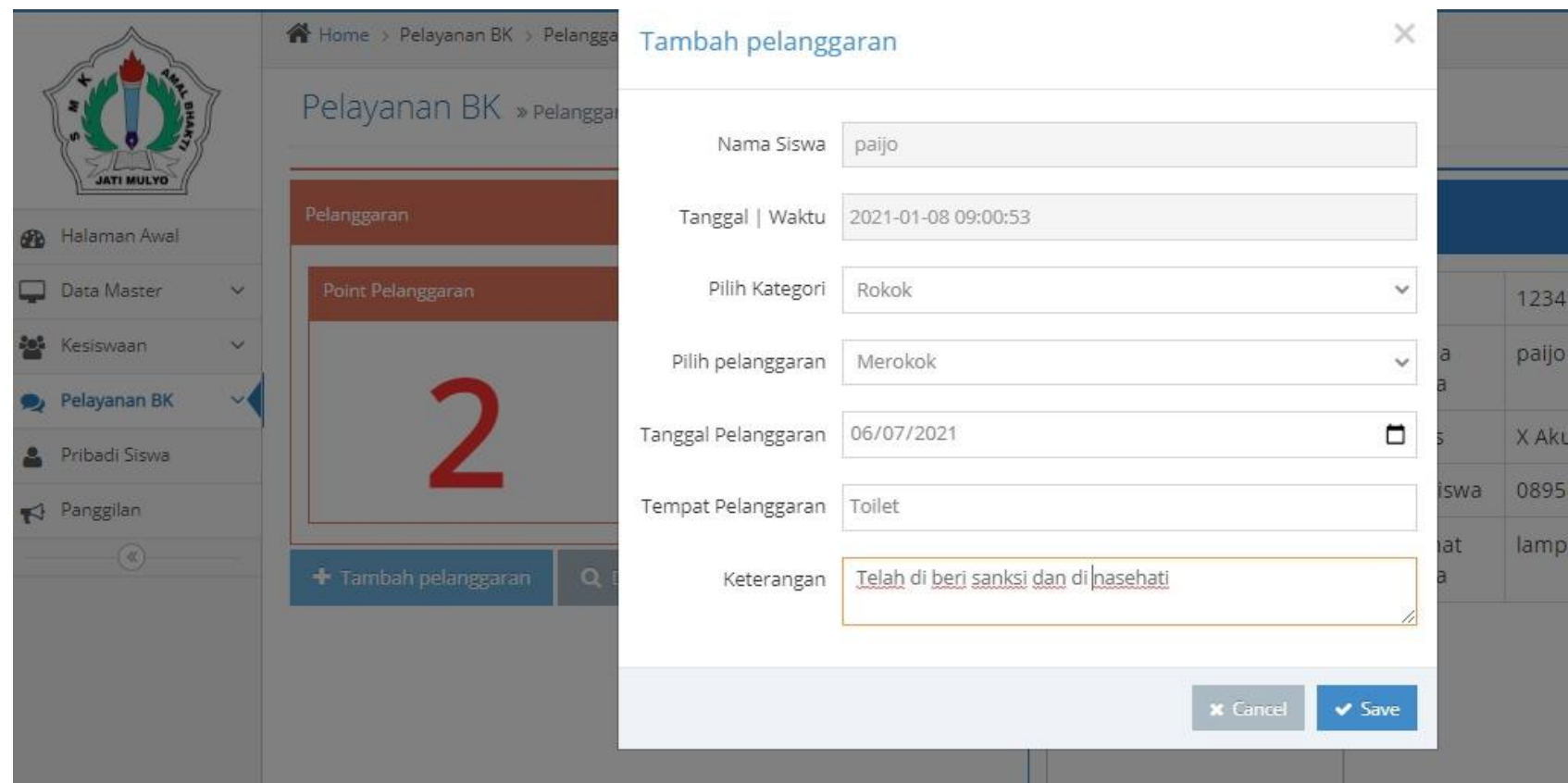

Figure 7. The application page if it is accessed by GTPD or a counselling teacher

From the figures above, the team tries to develop this program as simple as possible yet still maintain the function and usage of this web-based application. The menus are not too many because it is to minimize the perplexity of the users. Since the aims of this web-based application is to solve the problem occurred by the online activity, it should be users friendly. It also has to reach many people at any age level because technology can make people's life easier if it is well-designed and developed (Oktaviani \& Ayu, 2021; Styawati et al., 2021). To see the respondents' attitude toward counselling and guidance system, this team distributed a questionnaire to the participants. The statements given can be seen in the Table 3. 
Table 3. The respondents' attitude toward counselling and guidance system

\begin{tabular}{cl}
\hline No. & Statements \\
\hline 1 & $\begin{array}{l}\text { The web-based application of counselling and guidance is user friendly. } \\
\text { The web-based application of counselling and guidance is well-designed. }\end{array}$ \\
3 & $\begin{array}{l}\text { The web-based application of counselling and guidance helps me to communicate faster with the GTPD } \\
\text { or a counselling teacher. }\end{array}$ \\
4 & $\begin{array}{l}\text { The web-based application of counselling and guidance helps me to interact with the GTPD or a } \\
\text { counselling teacher during covid-19 pandemic. }\end{array}$ \\
6 & $\begin{array}{l}\text { The web-based application of counselling and guidance meets my needs. } \\
\text { Thearning during covid-19 pandemic. }\end{array}$ \\
\end{tabular}

After the questionnaire given to the respondents, the data were obtained and provided below in the Figure 8.

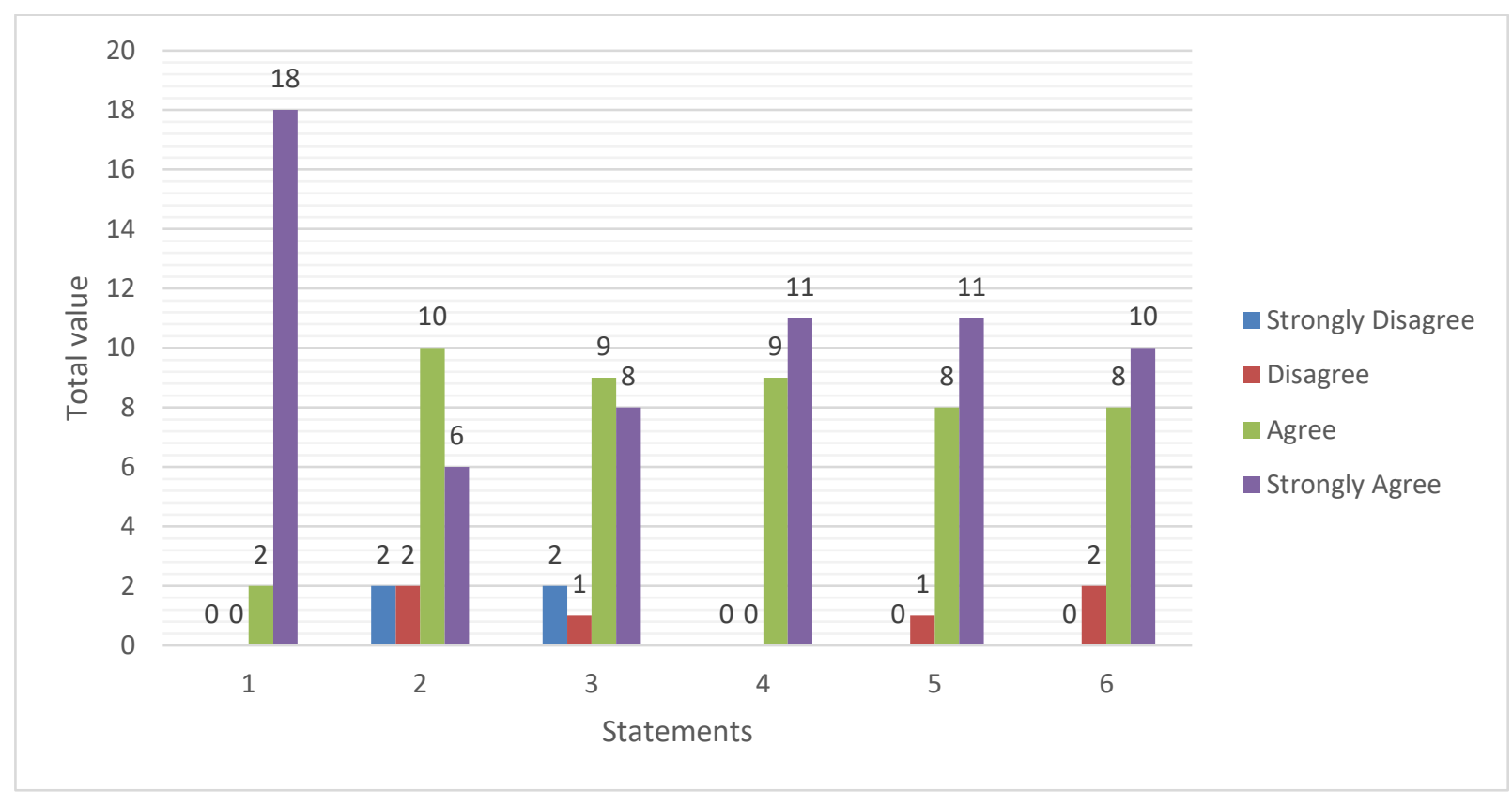

Figure 8. The data obtained from the Likert Scale questionnaire

Based on the figure 8 above, the team analyze it by grouping the response into two groups, positive respond and negative respond toward the use of a web-based application. The strongly disagree and disagree responses belong to negative group and agree responses belong to positive group as it is shown in the Table 4.

Table 4. A group of Negative and Positive Responses

\begin{tabular}{ccc}
\hline Scales & Negative response (\%) & Positive response 9\%) \\
\hline 1 & 0 & 100 \\
2 & 20 & 80 \\
3 & 15 & 85 \\
4 & 0 & 100 \\
5 & 5 & 95 \\
6 & 10 & 90 \\
\hline
\end{tabular}

From the Table 4, it can be seen that most respondents' answers were positive for every statement toward the use of a counselling and guidance web-based application during covid-19 pandemic. The highest percentage of negative response was $20 \%$ and the lowest percentage of positive response was $80 \%$. It can be concluded that the developing of a web-based application enhances the counselling and guidance system during covid-19 pandemic at SMA Amal Bakti Jati Mulyo, South Lampung. Finally, this program is ended by handling a souvenir from Universitas Teknokrat Indonesia to SMK Amal Bakti Jati Mulyo as a symbol of giving the counselling and guidance web-application (Figure 9). Besides, taking a picture together after the program was as a closing remark of this service program (Figure 10). 


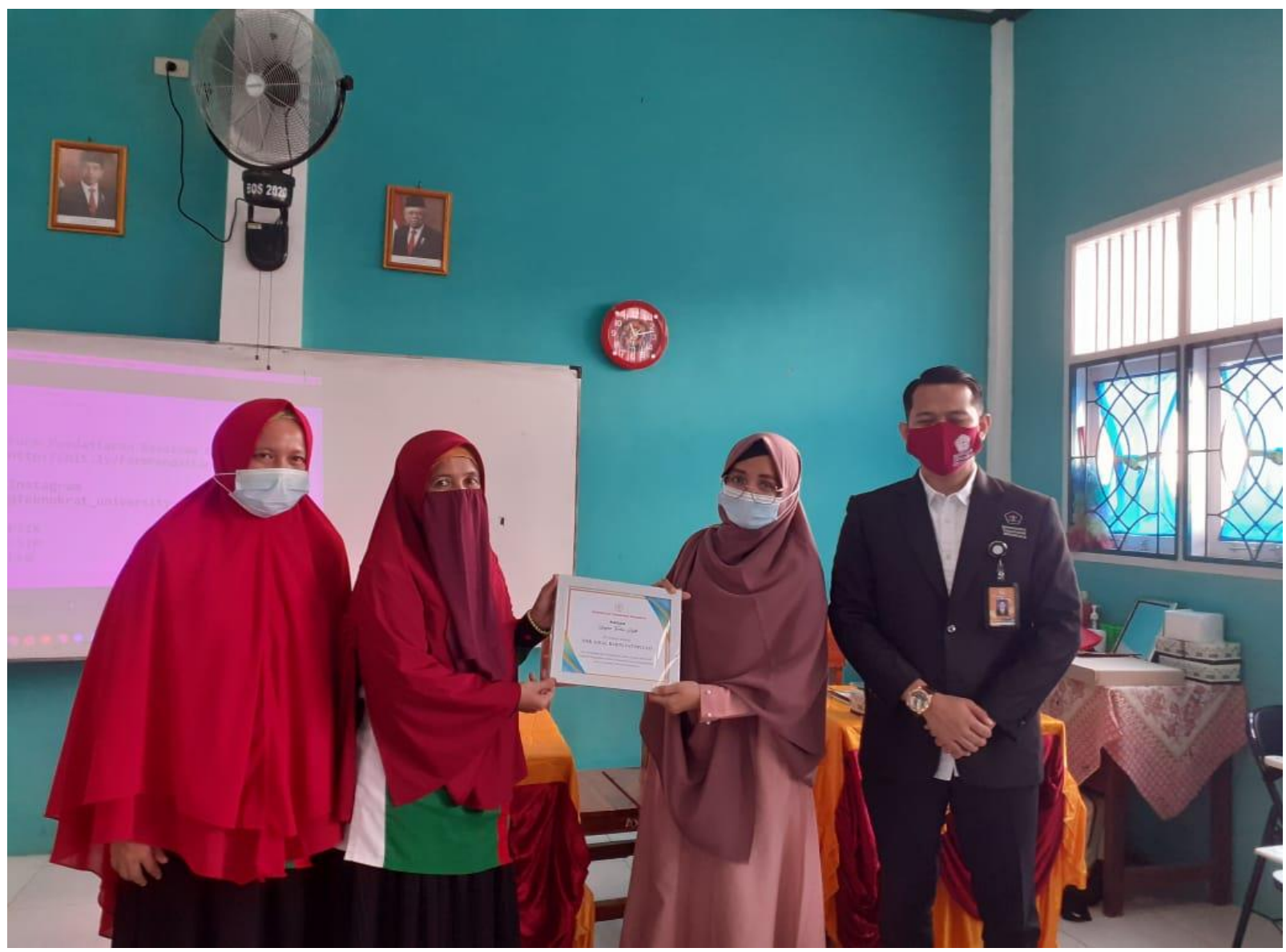

Figure 9. Handling a souvenir as a symbol of giving the application to the school

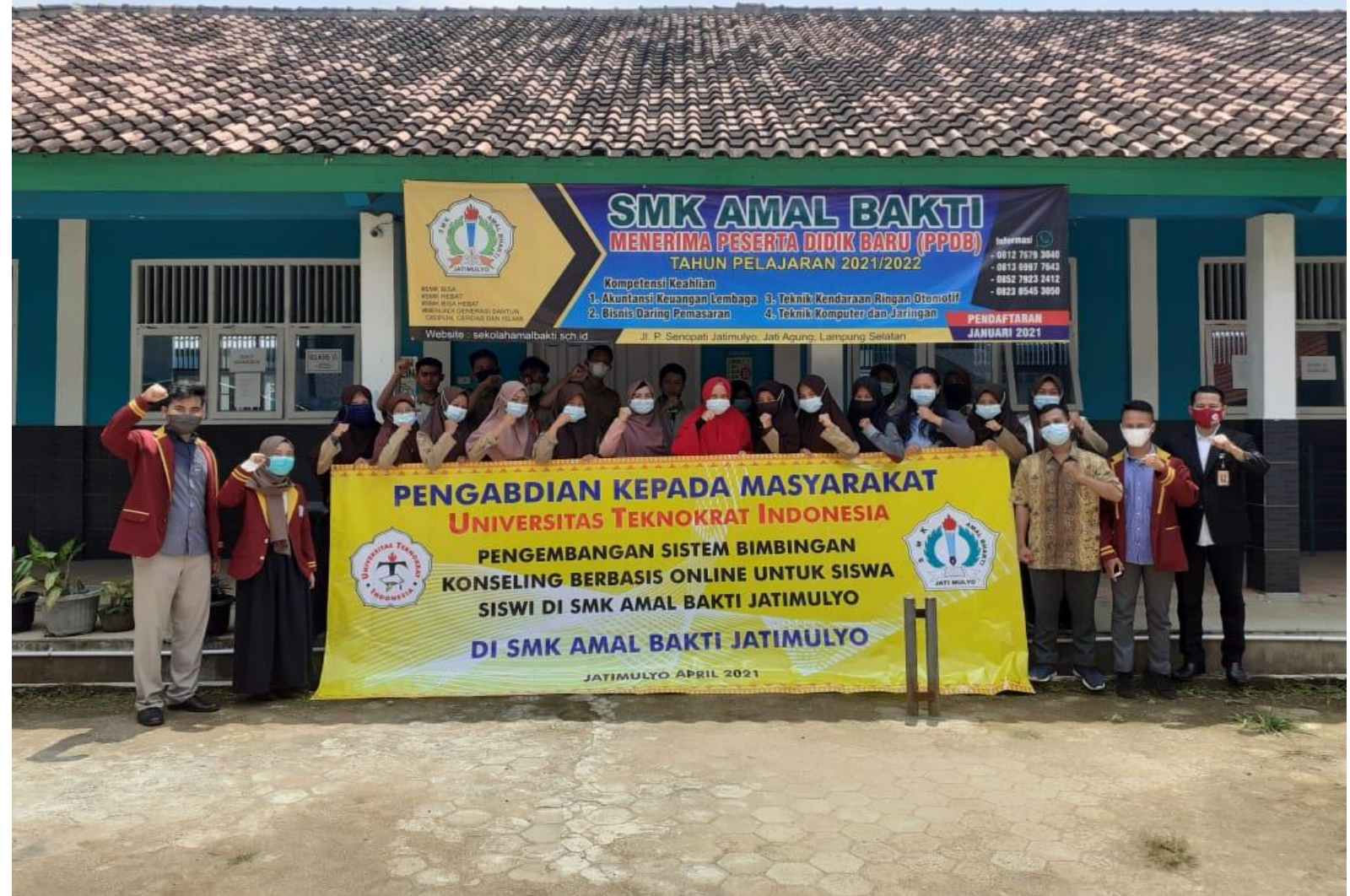

Figure 10. Taking a picture together as a closing remark of this program 


\section{CONCLUSION}

This service program does give an impact to the counselling and guidance system by developing a web-based application, especially during covid-19 pandemic. It helps students and GTPD or a counselling teacher communicate through technology that is user friendly. Besides, it also helps the school to monitor the students' psychology during online learning. Also, it successfully minimizes students' problems during online learning. Thus, the team does not only give a solution to the school but also boost teachers' confidence toward technology and support the decree of ministry of education to stay at home and learn from home to stop the spread of covid-19 virus.

\section{ACKNOWLEDGEMENTS}

The writers would like to show their gratitude to Rector of Universitas Teknokrat Indonesia for supporting this service program and also Teknokrat Education Foundation who has founded this program. Moreover, the writers also would like to say thank you to SMK Amal Bakti Jati Mulya of South Lampung who became the participants of this service activity.

\section{REFERENCES}

Aji, R. H. S. (2020). Dampak Covid-19 pada pendidikan di Indonesia: Sekolah, keterampilan, dan proses pembelajaran. SALAM; Jurnal Sosial \& Budaya Syar-I, 7(5), 395-402. https://doi.org/10.15408/sjsbs.v7i5.15314

Aminatun, D. \& Oktaviani, L. (2019). Memrise: Promoting students' autonomous learning skills through language learning application. Metathesis: Journal of English Language, Literature, and Teaching, 3(2), 214-224. http://dx.doi.org/10.31002/metathesis.v3i2.1982

Oktaviani, L., \& Ayu, M. (2021). Pengembangan sistem informasi sekolah berbasis web dua bahasa SMA Muhammadiyah Gading Rejo. Jurnal Pengabdian Pada Masyarakat, 6(2), 437-444. https://ppm.ejournal.id/index.php/pengabdian/article/download/731/420

Oktaviani, L. \& Desiarti, E. (2017). A lecturer's and students' perspective toward ethnic snake game in speaking class at Universitas Muhammadiyah Malang. TEKNOSASTIK: Journal Bahasa dan Sastra, 15(2), 53-59. https://doi.org/10.33365/ts.v15i2.98

Oktaviani, L., Aminatun, D., \& Ahmad, I. (2020). Peningkatan profesionalitas guru SDN 4 Mesuji Timur melalui program t2kt. INTEGRITAS: Jurnal Pengabdian, 4(2), 333-345. https://doi.org/10.36841/integritas.v4i2.786

Kemendikbud. (2020). Surat edaran nomor 4 Tahun 2020 tentang pelaksanaan kebijakan pendidikan dalam masa darurat penyebaran Corona Virus Disease (Covid-19).

Kemendikbud. (2020). Surat edaran nomor 15 Tahun 2020 tentang pedoman penyelenggaraan belajar dari rumah dalam masa darurat penyebaran Covid-19.

Kriksciuniene, D., Sakalauskas, V., \& Lewandowski, R. (2019) Evaluating the interdependent effect for Likert Scale Items. In: Abramowicz W., Corchuelo R. (eds) Business Information Systems Workshops. BIS 2019. Lecture Notes in Business Information Processing, vol 373. Springer, Cham. https://doi.org/10.1007/978-3-03036691-9_3

Simamora, M. W. B., \& Oktaviani, L. (2020). what is your favorite movie?: A strategy of english education students to improve english vocabulary. Journal of English Language Teaching and Learning, 1(2), 44-49. https://doi.org/10.33365/jeltl.vli2.604

Styawati, Oktaviani, L., \& Lathifah. (2021). Penerapan sistem pembelajaran dalam jaringan berbasis web pada Madrasah Aliyah Negeri 1 Pesawaran . Jurnal WIDYA LAKSMI (Jurnal Pengabdian Kepada Masyarakat), 1(2), 68-75. https://jurnalwidyalaksmi.com/index.php/jwl/article/view/15

Rikawati, K., \& Sintinjak, D. (2020). Peningkatan keaktifan belajar siswa dengan penggunaan metode ceramah interaktif. Journal of Educational Chemistry, 2 (2). 40-48. https://doi.org/10.21580/jec.2020.2.2.6059

Riskiono, S. D., \& Oktaviani, L., Sari, F. M. (2021). Implementation of the school solar panel system to support the availability of electricity supply at SDN 4 Mesuji Timur. IJISCS (International Journal of Information System and Computer Science), 5(1), 34-41. https://ojs.stmikpringsewu.ac.id/index.php/ijiscs/article/view/960/pdf

Widhiarso, P. (2010). Pengembangan skala psikologi: Lima kategori respons ataukah empat kategori respons? https://webcache.googleusercontent.com/search?q=cache:nV90znNil1IJ:https://widhiarso.staff.ugm.ac.id/files/ widhiarso_2010___respon_alternatif_tengah_pada_skala_likert.pdf+\&cd=1\&hl=id\&ct=clnk\&gl=id

Yazid, H., \& Neviyarni. (2021). Pengaruh pembelajaran daring terhadap psikologis siswa akibat Covid-19. Jurnal Human Care, 6(1), 207-213. https://doi.org/10.31004/edukatif.v3i5.864 